\title{
Comparing Oral and Written Cooking Recipes \\ Using Systemic Functional Grammar
}

\author{
Esti Sugiharti \\ English Department, Politeknik Negeri Bandung, Indonesia \\ Email: esti.sugiharti@polban.ac.id
}

\begin{abstract}
This article compares oral and written cooking recipes of the same food created by the same person, by using systemic functional grammar. The aim of the article is to find out the similarities and differences of the language used in both recipes. The data are obtained from Jamie Oliver's cooking show aired in a YouTube channel on how to make scones and the written recipe of the same food published in his website. The focus of the analysis is on the lexico-grammar of the clauses used in the texts. The result shows that there are more differences than similarities between the two texts. There are more clauses in the spoken text than those in the written text in terms of quantity and variety. In the ideational function, both texts have a similar variety of processes with the majority of material process showing imperatives of procedural texts and additional information using mental, existential, and relational processes, but in the written text there are two clauses using verbal process that are not found in the spoken text. In the interpersonal function, the two texts show demands of good and services and the use of modalities in expressing the expected results of the cooking process. In the spoken text, the relation between the cook and the audience is friendlier and closer than that in the written text. It is demonstrated in the use of vocatives and interrogatives that are not used in the written text. The textual functions show similar results in the use of conjunctions but the spoken text displays closer interpersonal textual functions found in the use of vocatives. The analyses of the three metafunctions of the two recipes may contribute to the study of food texts in linguistics that are relatively low compared to those in other disciplines.
\end{abstract}

Keywords: systemic functional grammar, cooking recipes, oral and written communication

\section{INTRODUCTION}

Food as an important aspect in human lives has attracted many scholars in many areas of studies. Research on texts about food has been widely conducted from many multidisciplines, such as philosophy, sociology, anthropology, economics and marketing (Gerhardt, Frobenius \& Ley, 2013) as well as linguistics. However, studies on food recipes from linguistic perspectives are relatively fewer than those in other areas (Klenová, 2010, p. 7). Hence, Klenova (2010) then conducts research on food recipes focusing on lexical level, syntax, and discourse (p. 8). Gerhardt, Frobenius and Ley (2013) also point out that amongst many studies on food, the intersection on food and language is rarely found. Therefore, with other scholars, Gerhardt develops an edited 
collection of studies on food and language which include recipe analysis (Gerhardt, Frobenius \& Ley 2013). Another recent study on food is a recipe analysis from cognitive linguistics (Shaarawy, 2015), and another one focusing on food from a pragmatic perspective (Fortunati, 2015).

Meanwhile, studies on systemic functional linguistics (SFL), or some linguists call it systemic functional grammar, have also been widely proliferated in many areas of studies. As Halliday, the father of SFL, has argued, there are "21 possible applications of SFL" (cited in Eggins, 2004, p. 2). Cordeiro (2018) also argues, "SFL is applied in a variety of contexts of study including media articles, political discourse in multimodality, physician patient communication, political discourse, pedagogy, creative writing and gender studies, and as methodology in organizational discourse studies" (p. 2).

Moreover, SFL approach is very important as it focuses on meaning making that is realized through grammar and choices of words. As the foundation of learning a foreign language is generally focused on grammar and vocabulary and how to use them in context situations, this SFL approach may help English language learners to express their meanings in creating or producing texts both in oral and written media. Talking and writing about food may also become an easy choice for foreign language learners as a practice to express their ideas in English. However, there have only been two studies on cooking recipes by using an SFL approach (Vogli, 2009) and (Castello, 2014). Although these two studies are important, they are limited to analyses of some extracts on food recipes presented on a TV show and printed texts as assignments of MA programmes, while in an SFL approach, it is important to analyze the whole text (Thompson, 2014).

Therefore, this article attempts to extend more studies on food recipes as a whole (not just extracts) using an SFL approach. In particular, this article aims to compare two recipes of the same food created by the same person but are presented in different media, that is a YouTube channel and a written recipe presented on a blog in order to find the similarities and differences of the language use in oral and written texts. The research question is as follows: What are the similarities and differences of the use of lexicogrammatical aspects in the two texts? Before analyzing the texts, a brief theoretical framework on SFL will be discussed. 


\section{THEORETICAL FRAMEWORK}

Systemic functional language (SFL) or some linguists call it functional grammar, as mentioned in the outset, concerns with the use of language and its purpose. As Thompson (2014) argues, the purpose of language is "to talk about things and events ... and to get things done" as well as to be used as "a kind of language-internal "service function"” (p. 8). He adds that the use of language also shows choices (pp. 7-8). As he further explains,

Functional Grammar sets out to investigate what the range of relevant choices are, both in the kinds of meanings that we might want to express (or functions that we might want to perform) and in the kinds of wordings that we can use to express these meanings; and to match these two sets of choices. In order to identify meaning choices, we have to look outwards at the context (Thompson, 2014, p. 9).

In the meaning making of the expressions, according to Halliday (1994), there are three functions: "the ideational (experiential and logical), interpersonal, and textual metafunction" (cited in Butt et al., 2000, p. 5). Butt at.al (2000) further explains that "the ideational metafunction uses language to represent experience"; "the interpersonal metafunction uses language to encode interaction"; and "the textual metafunction uses language to organise our experiential, logical and interpersonal meanings into coherent and, in the case of written and spoken language, linear whole" (p. 5). These three functions simultaneously make meanings of a text and are revealed or realized in the form of a clause. What is meant by functional grammar here "is not a set of rules but a set of resources for describing, interpreting, and making meaning" (Butt et al., 2000, p. 3). In discussing the meanings of the three metafunctions, Butt et al., (2000)'s source will be mostly used as it is easy to understand and clearly explained.

\section{Ideational function}

Ideational function or commonly called experiential function shows experiential meanings that function "to encode our experience of the world; that is, we use it to convey a picture of reality" (Butt et al., 2000, p. 46). Experiential function can be divided into "three functional constituents: PARTICIPANTS, PROCESS, and CIRCUMSTANCE" (Butt et al., 2000, p. 47). Participants may have roles as actor, agent, goal, carrier, and 
sayer, while process may consist of material, relational, and projecting (Butt et al., 2000, p. 47). Process may also be divided into doing, thinking which includes feeling and saying, and being (Butt et al., 2000, p. 50). In other words, process may be divided into material, mental, verbal, behavioral, existential and relational.

Butt et al. (2000, pp. 62-63) summarizes the experiential function in the following table.

Table 1. Summary of the Experiential Function

\begin{tabular}{|c|c|c|c|}
\hline Process type & Domain & Restriction & Participants \\
\hline $\begin{array}{l}\text { Material } \\
\text { Function: to construe } \\
\text { the material world of } \\
\text { doing }\end{array}$ & $\begin{array}{l}\text { outside activities } \\
\text { DOING something }\end{array}$ & $\begin{array}{l}\text { none } \\
\text { ANYONE/THING } \\
\text { can do }\end{array}$ & $\begin{array}{l}\text { Actor }=\text { doer } \\
\text { Goal }=\text { affected } \\
\text { Range = not affected } \\
\text { Beneficiary = to/for }\end{array}$ \\
\hline $\begin{array}{l}\text { Behavioral } \\
\text { Function: to construe } \\
\text { conscious behaviour }\end{array}$ & $\begin{array}{l}\text { physiological and } \\
\text { psychological } \\
\text { behaviour: the doing } \\
\text { version of mental or } \\
\text { verbal processes }\end{array}$ & needs consciousness & $\begin{array}{l}\text { Behaver }=\text { doer } \\
\text { Behaviour } / \text { Range }=\text { done }\end{array}$ \\
\hline $\begin{array}{l}\text { Mental } \\
\text { Function: to construe } \\
\text { and may project the } \\
\text { inner world of } \\
\text { consciousness }\end{array}$ & $\begin{array}{l}\text { inside activities } \\
\text { thinking, knowing, } \\
\text { liking, wanting, } \\
\text { perceiving }\end{array}$ & $\begin{array}{l}\text { needs consciousness } \\
\text { and human } \\
\text { characteristics }\end{array}$ & $\begin{array}{l}\text { Senser = doer } \\
\text { Phenomenon = thing } \\
\text { known, liked/disliked, } \\
\text { wanted, perceived }\end{array}$ \\
\hline $\begin{array}{l}\text { Verbal } \\
\text { Function: to construe } \\
\text { saying }\end{array}$ & $\begin{array}{l}\text { bringing the inside } \\
\text { outside: saying } \\
\text { something }\end{array}$ & $\begin{array}{l}\text { none } \\
\text { anyone/thing can say } \\
\mathrm{NB} \text { : inanimate saying } \\
\text { is close to identifying }\end{array}$ & $\begin{array}{l}\text { Sayer }=\text { doer } \\
\text { Verbiage }=\text { said } \\
\text { Receiver }=\text { said to } \\
\text { Target }=\text { said about }\end{array}$ \\
\hline $\begin{array}{l}\text { Existential } \\
\text { Function: to construe } \\
\text { existence }\end{array}$ & $\begin{array}{l}\text { introduce existence } \\
\text { of new Participants }\end{array}$ & none & Existent \\
\hline $\begin{array}{l}\text { Relational } \\
\text { Attributive } \\
\text { Function: to construe } \\
\text { relationships of } \\
\text { description }\end{array}$ & $\begin{array}{l}\text { to characterize or } \\
\text { assign membership to } \\
\text { a class }\end{array}$ & none & $\begin{array}{l}\text { Carrier: thing described } \\
\text { Attribute: description }\end{array}$ \\
\hline $\begin{array}{l}\text { Relational } \\
\text { Identifying } \\
\text { Function: to construe } \\
\text { relationships of } \\
\text { identification and } \\
\text { equation }\end{array}$ & $\begin{array}{l}\text { to decode known } \\
\text { meanings and encode } \\
\text { new meanings }\end{array}$ & none & $\begin{array}{l}\text { Identified = that which is to } \\
\text { be identified } \\
\text { Identifier = the new identity } \\
\text { Token = form } \\
\text { Value = function or role } \\
\text { Token represents Value } \\
\text { Value is represented by } \\
\text { Token) }\end{array}$ \\
\hline
\end{tabular}

(Butt et.al., 2003, pp. 62-63) 


\section{Interpersonal Function}

As Butt et al. (2000) points out, interpersonal function is used "to encode our interaction", which means "to interact with language and to express interpersonal meanings" (p. 86, emphasis in original). As summarized by Vogli (2009):

The basic interpersonal meanings refer to whether language is used to exchange information or goods or services. This is achieved by either demanding or giving and is realized at the lexicogrammatical level. Thus, we use a statement (declarative) to give information, and a question (interrogative) to demand information. We use a command or order (imperative) to demand goods and services, or to give orders or instructions. Procedural texts (such as recipes, manuals etc) are a good example of ordering goods and services. Although they are not really demands they have the form of orders, which are to be followed in order to have the desired result (p. 5).

The analysis of interpersonal function is focused on the time (tenses) and modality. In analyzing the interpersonal function, the most important focus is on the use of the relation within grammatical function, that is the subject and the finite which form the mood of the clause (Butt et al., 2000, p. 88). As Butt et al. (2000), further explains, "the Finite has two main interpersonal roles in the verbal group - it can be a sign of TIME in relation to the speaker, or a MODAL sign of the speaker's opinion" (p. 89), and the subject and the finite are called the mood or the mood block of the clause (p. 91) while the rest of the clause which is the predicator which may include a complement and/or adjunct is called residue (p. 93).

\section{Textual Function}

The textual function is used "to organize our experiential and interpersonal meanings into a linear and coherent whole" (Butt et al., 2000, p. 134). As they further explain,

English speakers and writers use the first position in the clause to signal to their audience what the message is about. In English the first position in a clause contains textual meanings because it signposts the development of a text. To analyze and discuss textual meanings we need a simple and distinct 
metalanguage: we call the first element THEME and the rest of the clause

RHEME (Butt et al., 2000, p. 135, emphases in original).

The theme is then classified into textual, interpersonal and topical (Butt et al., 2000, p. 137). They further explain that the textual theme may consist of conjunctions and the topical theme is the experiential meaning of the clause (p. 137), while the interpersonal theme can be "the Finite in interrogative clauses where it precedes the Subject and immediately signals that the speaker is demanding information" and "initial Vocative, and Mood and Comment Adjuncts" (p. 138).

All the three metafunctions are summarized by Matthiessen and Halliday (2014, p. 83) as follows:

Table 2. Summary of Three Metafunctions

\begin{tabular}{|l|l|l|l|}
\hline Metafunction & Clause as ... & System & Structure \\
\hline textual & message & THEME & Theme ^ Rheme \\
\hline interpersonal & exchange & MOOD & $\begin{array}{l}\text { Mood [Subject + Finite] + Residue } \\
{[\text { Predicator (+Complement) (+ Adjunct) }]}\end{array}$ \\
\hline experiential & representation & TRANSITIVITY & $\begin{array}{l}\text { Process + participant(s) (+circumstances), } \\
\text { e.g. Process + Actor + Goal }\end{array}$ \\
\hline
\end{tabular}

\section{Register}

Language also shows social and cultural contexts of situations. They are called field, which is "what's going on in the situation", tenor which is "who is taking part in the situation", and mode which shows "what role is being played by language and other semiotic systems in the situation" (Mathiessen \& Halliday, 2014, p. 33-34). As explained by Butt et al. (2000), field is "what is to be talked or written about"; tenor is "the relationship between the speaker and the hearer (or ... writer and reader); and mode is "the kind of text that is being made" (p. 5). These show that field is related to the ideational function; tenor is related to the interpersonal function; and mode shows the textual function.

\section{METHOD}

The analysis is focused on the clauses of the texts because as Matthiessen and Halliday (2014) argue, "clause is the central processing unit in the lexicogrammar - in the specific sense that it is in the clause that meanings of different kinds are mapped into 
an integrated grammatical structure" (p. 10). As Eggins (2004) points out, "one of Michael Halliday's major contributions to linguistics analysis is his development of a detailed functional grammar of modern English ... showing how simultaneous strands of meanings (the ideational, interpersonal and textual metafunctions) are expressed in clause structures" (p. 2). Therefore, the clauses in both of the spoken and written texts are analyzed to show the three-metafunctions meanings.

The data are obtained from one spoken text taken from a video of Jamie Oliver's show focusing on his demonstration of making scones (Oliver, 2017) and one written text taken from a written recipe of how to make scones entitled "Crumbliest Scones" published in his website (Oliver, n.d). Oliver's show and his written recipe have been chosen because Oliver is a chef who is internationally popular. Scone is selected as it is a common and popular food in English speaking countries, and it is easy to make so that the recipe is easily understood by learners of English as a foreign language.

There are several steps conducted in analyzing the texts. First, the texts are broken down into clauses and then each clause is analyzed based on the ideational function or experiential function, interpersonal function, and textual function. The following are examples of analysis of some clauses from the spoken text and the written texts.

One clause from the spoken text:

Clause 1 (cl. 1). So lovely people, we're going to make homemade scones.

\begin{tabular}{|l|l|l|l|l|l|l|}
\hline $\begin{array}{l}\mathrm{cl} \\
1\end{array}$ & independent & $\begin{array}{l}\text { So lovely } \\
\text { people, }\end{array}$ & we & \multicolumn{2}{|l|}{ re going to make } & $\begin{array}{l}\text { homemade } \\
\text { scone }\end{array}$ \\
\hline & Experiential & & $\begin{array}{l}\text { Participant } \\
\text { (actor) }\end{array}$ & Process (material) & Participant (goal) \\
\hline & Interpersonal & Vocative & Subject & Finite & Predicator & Complement \\
\hline & & & Mood block & Residue & \\
\hline & Textual & Interpersonal & Topical & & & \\
\hline & & Theme & Rheme & \\
\hline
\end{tabular}

One clause from the written text:

Clause 1 (cl. 1.) Scones are wonderfully British, delicious, and so simple

\begin{tabular}{|l|l|l|l|l|l|}
\hline cl & independent & Scones & are & $\begin{array}{l}\text { wonderfully British, } \\
\text { delicious, and so simple }\end{array}$ \\
\hline & Experiential & $\begin{array}{l}\text { Participant } \\
\text { (carrier) }\end{array}$ & \multicolumn{2}{|l|}{ Process (attributive) } & Participant (attributive) \\
\hline & Interpersonal & Subject & Finite & predicator & Complement \\
\hline & & Mood block & Residue & \\
\hline & Textual & Theme & Rheme & \\
\hline
\end{tabular}


Second, after all the clauses are analyzed in each function, the similarities and differences between the two texts are identified and discussed. Finally, in the discussion section, the results of this present study are compared with those of the previous studies on recipes analyzed by using an SFL approach (Vogli, 2009) and (Castello, 2014).

\section{RESULT AND DISCUSSION}

\section{RESULT}

There are 89 clauses in the spoken text and 55 clauses in the written text. There are significantly more clauses in the spoken text. In addition, in the spoken text, there are five short clauses that according to Eggins, such clauses are called minor clauses as they cannot be put into subject and finite (Eggins, 2004, p 166). The clauses are "Okay then", "Okay", "Okay for me”, "Mmm”, and "Oh yeah". However, there are no such expressions in the written text. These minor clauses are not included in the metafunctions analysis. So, there are 84 clauses in the spoken text and 55 clauses in the written text that are analyzed using the three metafunctions that are explained below.

\section{Ideational function}

In the ideational or experiential function, each of the clauses is analyzed based on the process, participants and circumstances. The results are as follows:

Table 3. Results of Ideational Function

\begin{tabular}{|l|l|l|}
\hline Process & Text 1 (spoken) & Text 2 (written) \\
\hline Material & $48(57.1 \%)$ & $42(76.3 \%)$ \\
\hline Behavioral & - & - \\
\hline Mental, cognition & $9(10.7 \%)$ & $3(5.4 \%)$ \\
\hline Mental, emotional & $4(4.7 \%)$ & - \\
\hline Existential & $1(1.1 \%)$ & $1(1.8 \%)$ \\
\hline Relational IDF & $5(5.9 \%)$ & $1(1.8 \%)$ \\
\hline Relational, attributive & $17(20.2 \%)$ & $6(10.9 \%)$ \\
\hline Verbal & - & $2(3.6 \%)$ \\
\hline Total & $84(100 \%)$ & $55(100 \%)$ \\
\hline
\end{tabular}

Both texts show the material process as the dominant processes as expected in a text on a recipe. However, in Text 2 the percentage of the material process is much higher. 
While in Text 1 the material process shows around half of the total clauses, in Text 2 it is around two thirds of the total clauses. This indicates that in the written recipe, it mainly focuses on the material process with only one third of additional information, while in the spoken text, there is more other additional information such as personal comments and personal affection which are almost half of the total clauses. Both texts show a variety of processes and both do not have a behavioral process. In Text 1 there are four mental, emotional processes but not in Text 2, but there are two verbal processes in Text 2 but none in Text 1 .

In terms of participants, in Text 1 , the spoken text, there are many various participants, such as we, I, the kids, it, you, you (ellipses in imperatives), they, lovely scones, clotted cream, some lovely jam, this gorgeous scone, and load of great stuff. These participants refer to the cook, the viewer and the scone and the ingredients, except for the kids. In Text 2, the written text, there are fewer types of participants. They are scones, $a$ five-year-old, I, anyone, you, it and they referring to the scones and they referring to general people in "so they say". However, these participants not only refer to the cook, the reader, and the scone, but also refer to people outside the cook and the reader; that is, people in general such as "a five-year old" in "even a five-year-old could make them", and anyone in "why anyone would prefer store-bought scones", and they in "so they say".

In the material processes, the actors in Text 1, the spoken text, show various actors, such as we, I, you, you (ellipses in imperatives), that, it and they. All of these actors refer to the cook, the viewer and the ingredients of the recipe. In Text 2, the written text, the actors include a five-year-old, they, you (ellipses in imperatives), you, it and they. Similarly, most of these actors refer to the cook, the reader and the ingredients in the recipe or the scone(s), but it is important to note that there is one actor, "a five-year-old", in "even a five-year-old could make them" refers to general people outside the cook, the reader, and the recipe. The goals in Text 1 are mostly the ingredients and the scones and some of the utensils, such as "my beautiful bakeware range" and "a baking sheet" and "the details" which refer to the written recipe. The circumstances show time, place and manner. Similarly, in Text 2, the goals are mostly the ingredients of the recipe, the scones, and the utensils. Also, the circumstances indicate time, place and manner.

From the results of the ideational function, it can be concluded that both in the spoken and the written texts, almost all of the types of processes may be used to realize 
the meaning of the recipes but with different amount of the types of the processes. In the spoken text, the material process shows half of the processes while in the written text comprises around two thirds of the processes. This means that in the spoken text, additional information that is not about the process of the making of the food is added more than that in the written text.

\section{Interpersonal function}

In the interpersonal function, modality, present tense and imperative are used in both texts. The spoken text shows declarative, imperatives and interrogatives while the written text only shows declaratives and imperatives. Similarly, most of the clauses in both texts show demand on 'goods and services' which can be found in the imperative clauses. In the mood block both texts show subject and finite in the present tense and modal finite. The use of present tense shows the description of the food and the modal finite functions as giving information on the steps to be followed in conducting the cooking.

In showing the steps of cooking, in the spoken text, there are quite a lot of the use of I ( 25 clauses) and we (inclusive) ( 5 clauses), instead of you (the viewer) (12 clauses) and ellipses you (14 clauses) in describing the steps or imperatives. Meanwhile, in the written text, the majority of the clauses use you to refer to the audience and ellipses you in imperatives and there is only one ' $I$ ' and it does not refer to the steps but the opinion of the writer: "I just can't imagine why anyone would prefer store-bought scones", and there is no ' $w e$ ' in the written text.

The following are examples of the use of ' $I$ ':

Table 4. Examples of the Use of ' $I$ '

\begin{tabular}{|l|l|}
\hline \multicolumn{1}{|c|}{ Text 1 (Spoken Text) } & \multicolumn{1}{|c|}{ Text 2 (Written Text) } \\
\hline $\begin{array}{l}\text { I'm going to be bigging up my beautiful bakeware } \\
\text { range }\end{array}$ & $\begin{array}{l}\text { Ijust can't imagine why anyone would prefer } \\
\text { store-bought scones }\end{array}$ \\
I will put a pinch of salt in \\
I want to put my pinch in, a couple of teaspoons of \\
sugar in. \\
I don't want it to be sweet, just kind of take it off of \\
savory \\
$\begin{array}{l}\text { I'm going to go in with two sort of semi heaps like that } \\
\text { teaspoon of baking powder }\end{array}$
\end{tabular}


Then what I want to do is just rub this together.

And then I've got 150 grams of lovely dried fruit random.

The following are examples of the use of ' $w e$ ':

Table 5. Examples of the Use of 'We'

\begin{tabular}{|l|l|}
\hline \multicolumn{1}{|c|}{ Text 1 (Spoken Text) } & Text 2 (Written Text) \\
\hline $\begin{array}{l}\text { So lovely people, we're going to make homemade } \\
\text { scones }\end{array}$ & - \\
We're going to use 500 grams of self-raising & \\
flour, 150 grams of diced unsalted butter. \\
So, we got some beautiful cutters here, all kinds \\
of shapes and sizes \\
$\begin{array}{l}\text { We got the fluted and the plain, a range of } \\
\text { different sizes as well }\end{array}$
\end{tabular}

Some examples of the use of ' $y$ ou' to refer to the audience are as follows:

Table 6. Examples of 'You', the Audience

\begin{tabular}{|l|l|}
\hline \multicolumn{1}{|c|}{ Text 1 (Spoken Text) } & \multicolumn{1}{|c|}{ Text 2 (Written Text) } \\
\hline $\begin{array}{l}\text { There you can put a little milk on top or a little } \\
\text { butter. }\end{array}$ & $\begin{array}{l}\text { and the second and third time you make them } \\
\text { you'll get the dough into a solid mass even } \\
\text { quicker, even better } \\
\text { If you work that dough harder } \\
\text { you will get a more perfect shape and cut out } \\
\text { So, what do you do? }\end{array}$ \\
$\begin{array}{l}\text { So guys, what are you waiting for? } \\
\text { and use your thumbs and forefingers to break up } \\
\text { the butter } \\
\text { so you get little cornflake-sized pieces. }\end{array}$ \\
\hline
\end{tabular}

The examples of the use of ellipses ' $y o u$ ' in imperatives are as follows:

Table 7. Examples of Ellipses 'You'

\begin{tabular}{|l|l|}
\hline \multicolumn{1}{|c|}{ Text 1 (Spoken Text) } & \multicolumn{1}{|c|}{ Text 2 (Written Text) } \\
\hline Brush them on top. & $\begin{array}{l}\text { Make a well in the middle of the dough } \\
\text { add the eggs and milk } \\
\text { Cook those for about } 15 \text { minutes } \\
\text { So, look. }\end{array}$ \\
This weekend, make some scones. & $\begin{array}{l}\text { Drain your soaked fruit } \\
\text { add that to the mixture }\end{array}$ \\
Go on for it. & Add a tiny splash of milk \\
\hline
\end{tabular}


The use of $I$, we, you, and ellipses you may show the closeness between the speaker and the audience.

Another example of the closeness between the speaker and the audience can be found in the uses of vocatives such as "So lovely people" in "So lovely people, we're going to make homemade scones" and "So guys" in "So guys, what are you waiting for?" in the spoken text. These vocative phrases are used to address the audience to indicate not only the closeness but also friendliness between the speaker and the audience. However, these kinds of vocatives are not used in the written text. Therefore, the interpersonal relation is closer and friendlier in the spoken text than that in the written text.

Modality is used in both texts. The following are examples of the use of modality:

Table 8. Examples of the Use of Modality

\begin{tabular}{|l|l|}
\hline Text 1 (Spoken Text) & Text 2 (Written Text) \\
\hline You can do it & $\begin{array}{l}\text { even a five-year-old could make them } \\
\text { I'll cover it }\end{array}$ \\
I'll let it chill out in the fridge & why anyone would prefer store-bought scones \\
And then I'll roll it out in about half an hour & the shorter and crumblier your scones will be \\
They're going to cook at the same time & and they'll be really great \\
There you can put a little milk on top or a little & you'll get the dough into a solid mass even \\
butter. & $\begin{array}{l}\text { quicker, even better } \\
\text { they will rise better that way } \\
\text { you will get a more perfect shape and cut out } \\
\text { You can see }\end{array}$ \\
& $\begin{array}{l}\text { you can just pop the little rounds of frozen dough } \\
\text { into the oven }\end{array}$ \\
\hline
\end{tabular}

The modality in both texts show opinion and mostly show the future expected results of the steps that are shown in the spoken text, and will be gained if the reader follows the steps in the written text. 


\section{Textual function}

The results of the textual analysis are presented in the table as follows:

Table 9. Results of Textual Function

\begin{tabular}{|l|c|c|c|c|c|}
\hline & \multicolumn{5}{|c|}{ Textual meaning } \\
\hline $\begin{array}{l}\text { Text } 1 \\
\text { (Spoken Text) }\end{array}$ & Textual & Topical & Interpersonal & No Theme & Total Clauses \\
\hline $\begin{array}{l}\text { Text } 2 \\
\text { (Written Text) }\end{array}$ & 33 & 50 & 4 & 0 & 84 \\
\hline
\end{tabular}

From the table above, it can be seen that in the spoken text, topical themes are dominant as expressed in the direct and closer interpersonal relations between the chef ' $I$ ' and 'you' the audience. It is assumed that when the chef is demonstrating the cooking, the audience is there watching the process. Meanwhile, in the written text, there are fewer topical themes than the textual themes. In the textual function, both texts show topical and textual meanings in the themes of the clauses. But in the spoken text, there are four interpersonal themes expressed in the vocatives, "so lovely people" and "so guys", and interrogatives, "So what do you do?" and "(is it) clotted cream or jam first?", while there is no interpersonal theme in the written text. This may indicate that in the written text, the interpersonal relation between the writer and the reader is more distant compared with that of the spoken text.

The textual theme in both spoken and written texts show similar functions that indicate the time sequence in the procedural texts such as "and", "then", "just after", "and then", "as soon as", "until"; cause-effects such as "so" and "because"; and conditional "if". However, such conjunctions appear more in the written text than in the spoken text.

\section{DISCUSSION}

Compared with the studies on recipes using an SFL approach in the two previous studies conducted by Vogli (2009) and Castello (2014), the present research shows similarities and differences. The main similarity is that recipes show procedural clauses and the majority of the clauses are imperatives. In the ideational function, in this present and previous studies, the majority of the clauses show material, mental, and relational 
processes. In the interpersonal function, this present and previous studies show similar clauses that include imperatives and modal clauses. Also, in the textual function, the present study and the previous ones show similar results in the use of conjunctions.

However, there are quite a lot of differences. First, in the present study, there are more various clauses used in the text, especially in the spoken text. It shows minor clauses such as "Okay then", "Okay", "Okay for me", "Mmm", and "Oh yeah". They are not found in the previous studies. The second difference is that the present study shows more variety in the ideational function in that it shows existential processes in "There's load of great stuff' in the spoken text and "There's a magic hour" in the written text. Such clauses are not found in the previous studies. Also, there are verbal processes such as "what I say" and "so they say" in the written text. These verbal processes are not found in the previous studies. The third difference is that in the present study, it can be found that the text uses vocatives "So lovely people" and "So you guys" in the spoken text that indicate friendlier and closer relations between the speaker and the audience. These vocatives are not found in the previous studies.

There are more varieties of clauses found in this present study. This may be because this study uses the complete texts while in the previous studies, they only include extracts of short texts that may exclude several important clauses. Therefore, in applying an SFL approach, it is important to use the data taken from a complete text.

\section{CONCLUSION}

The application of SFL has demonstrated that it shows the meaning in the three metafuncions of each clause in both spoken and written texts. The present study shows more different results than the similarities. The spoken text uses more clauses both in the number and the variety of clauses although both texts have a similar topic and are delivered by the same person. It also shows more variety of clauses compared with the previous studies. The significant difference is that the spoken text in the present study shows minor clauses and the use of vocatives that cannot be found in the written text in the present study. However, in the written text, it includes verbal processes that are not found in the spoken text. These findings are not found in the previous studies. 
The results of this present study may contribute to research on texts about food in linguistics areas and also may help students of English as a foreign language to produce texts about food, especially in producing recipes both in oral and written communication. For further research, it might be fruitful to analyze spoken and written texts on other areas such as travel guide texts related to food travel or places.

\section{REFERENCES}

Butt, D. et.al. (2003). Using functional grammar: An explorer's guide. (2 ${ }^{\text {nd }}$ ed.) Sydney: National Centre for English Language Teaching and Research, Macquarie University.

Castello, D. (2014). A comparison of three recipes using systemic functional grammar. [Unpublished Master of Arts in Applied Linguistics Module 3 Assignment]. ELAL College of Arts \& Law, The University of Birmingham.

Cordeiro, C.M. (2018). Using systemic functional linguistics as method in identifying semogenic strategies in intercultural communication: A study of the collocation of "time" and "different" by Swedish managers with international management experiences. Journal of Intercultural Communication Research 47 (3), 207-225. DOI: 10.1080/17475759.2018.1455601.

Eggins, S. (2004). An introduction to systemic functional linguistics. $\left(2^{\text {nd }}\right.$ ed.) London and New York: Continuum International Publishing Group.

Fortunati, L. (2015). The recipe: the queen of pragmatics. An Italian case study. Journal for Communication Studies 8 (2): 27-48.

Gerhardt, C., Frobenious, M. and Ley, S. (Eds). (2013). Culinary linguistics: The chef's special. Amsterdam: John Benjamins.

Klenová, D. (2010). The language of cookbooks and recipes. [Unpublished Master's Diploma Thesis]. Department of English and American Studies, Faculty of Arts, Masaryk University.

Matthiessen, C., \& Halliday, M.A.K. (2014). Halliday's introduction to functional grammar $\left(4^{\text {th }}\right.$ ed.). Abingdon: Routledge.

Oliver, J. (2017). How to make scones. [Cooking show]. YouTube. https://www.youtube.com/watch?v=BVNhJXa5W74

Oliver, J. (n.d.). Crumbliest Scones. [Blog]. Retrieved on 27 August 2020 from https://www.jamieoliver.com/recipes/fruit-recipes/crumbliest-scones/

Shaarawy, H.Y. (2015). Imperatives in written English cooking recipes: A cognitive linguistics analysis. English Language and Literature Studies (ELLS) 10 (1), 125168.

Thompson, G. (2014). Introducing functional grammar. London and New York: Routledge.

Vogli, S. (2009). A systemic functional analysis of three cooking recipes. [Unpublished Master of Arts in Applied Linguistics Paper]. CELS, The University of Birmingham. 